\title{
W obronie autonomii historii w muzeum
}

Monika Stobiecka, Rafał Stobiecki

TEKSTY DRUGIE 2020, NR 4, S. 86-106

DOI: $10.18318 /$ td.2020.4.6 | Monika Stobiecka - ORCID: 0000-0003-3774-6159 Rafał Stobiecki - ORCID: 0000-0002-1458-1657

Histeria wokół przeszłości wciąż trwa, przeszłość to ulubiona guma do żucia intelektualistów, historyków, pisarzy, akademików, mediów i polityków.

Dubravka Ugresič ${ }^{1}$

\section{Wprowadzenie}

Na naszych oczach dokonuje się zasadnicza zmiana miejsca historii w kulturze czy też w intelektualnym instrumentarium współczesnego człowieka. Zmiana ta w jednakowym stopniu odnosi się zarówno do zakorzenionych w tradycji XIX-wiecznej jej fundamentów jako nauki, jak i do funkcji, które miałaby pełnić. Przez wiele stuleci była ona częścią kultury opartej na słowie, dziś zastępuje ją coraz częściej historia oparta na obrazie. Dominowały w niej zasady rozumowego doświadczania świata, obecnie coraz częściej odwołuje się ona do emocji. Jej poznawcza funkcja, będąca rodzajem samowiedzy człowieka,

D. Ugresič Nowi barbarzyńcy, „Gazeta Wyborcza"12-13.V.2007.

\section{Monika Stobiecka -}

historyczka sztuki i archeolożka, adiunkt na Wydziale „Artes Liberales" Uniwersytetu Warszawskiego. Laureatka „Diamentowego Grantu" (2014), stypendystka Fundacji z Brzezia Lanckorońskich (2016),

Fundacji Kościuszkowskiej (2018), Fundacji na rzecz Nauki Polskiej (2019). Interesuje się studiami muzealnymi, krytycznymi studiami nad dziedzictwem, teorią i metodologią archeologii oraz prądami nowej humanistyki.

Rafał Stobiecki - historyk historiografii. Prof.zW., kierownik Katedry Historii Historiografii i Nauk Pomocniczych Historii w Instytucie Historii U Główne zainteresowania badawcze: historiografia okresu PRL-u, rosyjska i radziecka historiografia XIX iXX wieku, emigracyjne dziejopisarstwo polskie po 1945 roku, teoria historiografii. Stypendysta Fundacji Kościuszkowskiej (2010). 
zastępowana jest funkcją emancypacyjną, której zwolennicy postawili sobie za cel demaskowanie różnych praktyk działania władzy zmierzającej do opresji i wykluczania. Te same zmiany można przypisać muzeom, które odchodząc w latach 90. XX wieku od tradycyjnych modeli wystawienniczych, skrytykowanych przez reprezentantów „Nowej Muzeologii”, przeobraziły się w instytucje demokratyzujące, włączające, angażujące wielozmysłowo w imponujące spektakle muzealne ${ }^{2}$.

Nie jest naszą intencją jednostronna krytyka tych, wyrastających zarówno z przemian w obrębie humanistyki i studiów muzealnych, jak i w dużym stopniu z nieuchronnych zmian cywilizacyjnych. Chcielibyśmy zwrócić uwagę na ten ich wymiar, który wiąże się z tożsamością historii jako dziedziny wiedzy, zastanowić się nad pytaniem, co współczesność zmienia w sposobach jej rozumienia i wykorzystywania. W jaki zaś sposób te nowe formy praktykowania historii dochodzą do głosu w muzeach, jakie obietnice i zagrożenia ze sobą niosą.

Tekst intencjonalnie podzielony został na dwie części. Pierwsza będzie miała charakter wprowadzający, poświęcona będzie analizie zjawisk w obrębie samej, rozumianej szeroko historiografii oraz procesów niejako wobec niej zewnętrznych, które uważamy za typowe dla współczesnego świata, a których związek ze sposobami postrzegania czy użytkowania historii nie zawsze bywa dostrzegany. Druga cześć będzie miała charakter egzemplifikacyjny i dotyczyć będzie roli/ról historii w muzeum, w którym to w sposób szczególny kumulują się obserwowane przez nas zjawiska. To one bowiem, jak nam się wydaje, w największym stopniu rozstrzygają dziś o miejscu wiedzy o przeszłości w dyskursie publicznym.

\section{Tożsamość współczesnej historiografii}

Nie ulega wątpliwości, że historiografia akademicka, głęboko zakorzeniona w XIX-wiecznej wizji nauki historycznej, jest dziś marginalizowana. Zastępują ją różnego typu historie alternatywne. Wyrastają one ze sprzeciwu wobec dominującej do niedawna historii akademickiej, manifestującej się w postaci pisanej narracji historycznej, poddanej metodologicznym rygorom tradycyjnego

2 D. Folga-Januszewska Obraz, narracja, pamięć. Czy możliwe jest wyobrażenie przeszłości w muzeum?, w: Historia Polski od-nowa. Nowe narracje historii i muzealne reprezentacje przeszłości, red. R. Kostro, K. Wóycicki, M. Wysocki, Muzeum Historii Polski, Warszawa 2014, s. 71-87; tamże I. Kąkolewski Co decyduje i będzie decydować o atrakcyjności przekazu w muzeum historycznym? Kilka refleksji i proroctw, a może tylko utopistycznych marzeń, s. 108-114. 
warsztatu historycznego, zdefiniowanego przez klasyczną epistemologię historii. W ramach szeroko rozumianych historii alternatywnych mieszczą się różne formy: historie audiowizualne i wizualne, historie multimedialne, wirtualne i interaktywne, historie mówione, historie kommemoratywne, historie performatywne, wreszcie literatura historyczna ${ }^{3}$. Ich cechą wspólną jest to, że starają się one w różny sposób łączyć dwa dyskursy - nauki i sztuki. Odwoływać się poza racjonalną argumentacją do świata wizualności i zmysłowości ${ }^{4}$. W powszechnym odbiorze to wizje przeszłości obecne w owych historiach alternatywnych kształtują współczesne wyobrażenia o przeszłości. Młodzi autorzy tomu Historia w mediach piszą we wprowadzeniu do niego m.in.:

Gdyby zapytać historyka czym się zajmuje, to odpowie: badaniem historii, czytaniem opracowań naukowych, analizą źródeł, pisaniem publikacji, wydawaniem artykułów, siedzeniem w archiwach, nauczaniem dzieci w szkole, prowadzeniem zajęć na uczelniach, ewentualnie pracy, w muzeum lub jako przewodnik. Natomiast gdyby spytać przeciętnego człowieka, skąd czerpie swoją wiedzę o historii, to bez wahania odpowie, że oglądał niedawno Gladiatora i Szeregowca Ryana, natomiast jeśli mamy do czynienia z młodszą osobą, to zarzuci nas tytułami takich gier jak Call of Duty, Medieval Total War czy też niezniszczalnymi seriami Civilisation i Age of Empires. Zatem w końcu warto odpowiedzieć na pytanie co z nami historykami, skoro i tak to już nie my decydujemy o tym, jaką historię mają poznać obywatele tego świata. To na nas ciąży odpowiedzialność na tym, aby drogi nauki historycznej i przekazu historycznego nie rozeszły się, ponieważ byłoby to zgubne w konsekwencjach dla obu z tych rzeczy. ${ }^{5}$

3 P. Witek, M. Mazur, E. Solska Wprowadzenie, w: Historia w kulturze współczesnej. Niekonwencjonalne podejścia do przeszłości, red. P. Witek, M. Mazur, E Solska, Wydawnictwo UMCS, Lublin 2011, s. 11-12. Na marginesie warto dodać, że takie szerokie potraktowanie historii alternatywnych nie wydaje się nam do końca przekonujące, gubi ich specyfikę, łączy ze sobą zjawiska rzeczywiście nowe (gry komputerowe) z tymi istniejącymi od stuleci (powieść historyczna). Zob. także Historia w przestrzeni publicznej red. J. Wojdon, PWN, Warszawa 2018. Na temat historii alternatywnych z punktu widzenia literaturoznawczego por. N. Lemann Historie alternatywne isteampunk w literaturze. Archipelagi badawczo-interpretacyjne, Wydawnictwo UŁ, Łódź 2019.

4 T. Thiemeyer Narracja symultaniczna - opowiadanie w muzeum, w: Jak w XXI wieku opowiadać historię. Narracja jako problem teoretyczny i praktyczny w niemieckich naukach o historii, kulturze i literaturze, wyb., wstęp i opracowanie J. Kałążny, przeł. J. Kałążny, M. Wojtyna, Wydawnictwo Nauka i Innowacje, Poznań 2019, s. 385.

5 A. Świątek Przedmowa, w: Historia w mediach, red. M. Kijewski, A. Świątek, Wydawnictwo AT, Kraków 2007, t. 1, s. 7. 
Współczesna historiografia zmaga się także z nowym rozumieniem kategorii „historyk”. Pośrednim rezultatem intelektualnej prowokacji, jaką stanowił postmodernizm, było obwieszczenie poglądu o „zniknięciu” autora. Jego miejsce zaczęły wypełniać bezosobowe dyskursy, kształtujące rzeczywistość i człowieka, anonimowe wpisy na portalach. Zajmują one miejsce autora i przemawiają zamiast niego. Drugie przesłanie ma zupełnie inny wymiar. Współczesna kultura, demokratyzując dostęp do wiedzy o przeszłości, sprawia, że każdy może być historykiem. Pozbawia zatem środowisko historyczne, towarzyszącego mu od początku XIX stulecia wymiaru cechowego (historykiem mógł być ten, kto ukończył studia historyczne, wykazał się pewnymi umiejętnościami warsztatowymi, spełniał określone kryteria etyczne związane z byciem człowiekiem nauki). Współczesny świat uprawomocnia występowanie w roli historyka - polityka, dziennikarza, pisarza czy reżysera, nie mówiąc już o wielu przedstawicielach nauk humanistycznych i pracownikach muzealnych zajmujących się przeszłością ${ }^{6}$ W konsekwencji taka zmiana pozycji historyka, potencjalnie uprawomocnia tym samym każdą wypowiedź o przeszłości, bez względu na to, czy jest ona wynikiem krytycznego namysłu nad źródłami, czy też wytworem dowolnej fantazji autora.

Stosunek środowiska akademickich historyków do zmieniających się form obecności historii w przestrzeni publicznej waha się od deklaracji pełnych entuzjazmu, do daleko idącego sceptycyzmu. Sytuacja jednak powoli zaczyna się zmieniać. Pojawiają się nowe prace dotyczące interesującej nas problematyki, kształtują się powoli podstawy nieobecnych na gruncie polskim subdyscyplin, takich jak np. historia wizualna, historia środowiskowa, historia dźwięku czy historia zwierząt. Ostatni, XX Powszechny Zjazd Historyków Polskich w Lublinie (18-20 września 2019 roku) był niewątpliwie pierwszym takim spotkaniem, podczas którego zauważalne było otwarcie środowiska na inne formy dyskursu historycznego. W programie zjazdu znalazły się pokazy filmów historycznych, panel o muzeach historycznych i ich społecznych funkcjach, konkursy na najlepsze gry historyczne (komputerowe i planszowe).

6 Na marginesie zaznaczmy, że taka strategia może niekiedy przynosić ciekawe efekty poznawcze. Zob. np. P. Witek Andrzej Wajda jako historyk. Metodologiczne studium z historii wizualnej, Wydawnictwo UMCS, Lublin 2016.

7 Tylko na temat historii wizualnej zob. wspomnianą już pracę P. Witka, książkę D. Skotarczak Historia wizualna, Wydawnictwo UAM, Poznań 2012; Fotohistoria: fotografia w przedstawianiu przeszłości, red. V. Julkowska, Wydawnictwo IH UAM, Poznań 2012. 
Zjazd zakończył się zaś efektownym pokazem grup rekonstrukcyjnych zorganizowanym na lubelskim stadionie sportowym ${ }^{8}$.

\section{Historia w świecie kultury masowej}

Zasygnalizowanym wyżej zjawiskom i tendencjom wewnątrz historiografii towarzyszą przemiany charakterystyczne dla świata późnego kapitalizmu. Można wręcz stwierdzić, że pozostają z nimi w „dialektycznym związku”.

Po pierwsze, mamy na myśli fenomen komercjalizacji ${ }^{9}$ W otaczającej nas rzeczywistości historia staje się towarem, konkurującym na rynku z innymi dobrami. Żyjemy w świecie producentów i konsumentów historii, których role często się przenikają. Historia jest tak eksponowana, aby uczynić ją wartą przeczytania, obejrzenia, zwiedzenia czy przeżycia, oczywiście za odpowiednią opłatą ${ }^{10}$. Komercyjny wymiar przeszłości nie omija także, szczególnie nas interesujących, muzeów"1. Choć artykułowane w latach 9o. ubiegłego wieku obawy muzealników i historyków przed „disneylandyzacją" muzeów nie potwierdziły się w całości, to jednak do dziśs stanowi ona wyzwanie dla historycznych placówek muzealnych. W dalszym ciągu grozi im wyłączne wpisanie w kontekst kultury popularnej. Są one często "przedsiębiorstwami”

8 Zob. https://xxpzhp.umcs.lublin.pl/Program\%20XX\%20PZHP.pdf (6.01.2020). Zob. także M. Wolniewicz Historia historiografii na XX Powszechnym Zjeździe Historyków Polskich, Lublin, 18-20 września 2019 r., "Klio polska. Studia i materiały z dziejów historiografii polskiej” 2019 nr 11, S. 131-139.

Kwestia ta była dotychczas dostrzegana przede wszystkim w nurcie dotyczącym heritage industry. Zob. np. G.J. Ashworth, From History to Heritage - From Heritage to Indentity. In Search of Concepts and Models, w: Building a New Heritage. Tourism, Culture nad Indentity in New Europe, Routledge, London-New York 1994. Z kolei ciekawym przykładem wykorzystania zjawiska komercjalizacji do badań historycznych może być nurt w historiografii niemieckiej zajmujący się historią przedsiębiorstw. Zob. np. V. Damm Historia i funkcje jubileuszy historycznych w świecie biznesu i pracy od XIX wieku po współczesność, w: Historia w kulturze ponowoczesnej . Koncepcje - metody - perspektywy badawcze, red. M. Reznik, M. Saryusz-Wolska, S, Stach, K. Stroll, Universitas, Kraków 2017, s. 63-80. dzenie, w: Historia w kulturze ponowoczesnej... s. 22-27. chęcała, by tworząc współczesną ekspozycję muzealną, zwracać uwagę, aby czas jej zwiedzania odpowiadał długości filmu fabularnego, cena biletu nie przekraczała ceny podstawowego zestawu w McDonald's, a forma przekazu przypominała formułę CNN". P. Kowal Społeczny, cywilizacyjny i polityczny kontekst polskiego boomu muzealnego, w: Muzeum i zmiana. Losy muzeów narracyjnych, red. P. Kowal, K. Wolska-Pabian, Universitas, Warszawa-Kraków 2019, s. 45. 
oferującymi odwiedzającym szeroką gamę usług od gastronomii po sklepy z pamiątkami. Tak zresztą piszą o nich chociażby przedstawiciele studiów turystycznych, wskazując, że muzea wobec obecnych realiów rynkowych powinny przybrać formę przedsiębiorstw, a co za tym idzie: „traktować swoje zbiory jak produkt, który należy sprzedać, stosować różne zabiegi reklamowe, ułatwiające upowszechnienie zbiorów, organizować coraz atrakcyjniejsze formy zapoznania zwiedzających ze zgromadzonymi zbiorami, poszerzać tematykę oraz krąg zwiedzających"12.

Komercjalizacja historii jest fragmentem komercjalizacji życia. Obecnie tylko historia, w szerokim znaczeniu tego słowa, atrakcyjnie „opakowana" $\mathrm{i}$ intensywnie reklamowana może zyskać potencjalnych odbiorców. Nowym zjawiskiem jest turystyka historyczna na dotychczas niespotykaną skalę, często oparta na schemacie $3 \mathrm{E}$ (entertainment, excitement, education - rozrywka, ekscytacja, eduka(ja) $)^{13}$. Gdy wpisuje się w sentymentalną potrzebę odwiedzenia utraconych stron rodzinnych, nie budzi zwykle wątpliwości. Co zrobićjednak, kiedy współczesne rosyjskie biuro turystyczne oferuje wycieczkę na Sołowki czy na Magadan i w reklamie pisze, że pełnię wrażeń osiągniemy dzięki łagrowej odzieży i kilofowi? ${ }^{14}$

Komercjalizacja towarzyszy też rynkowi książek i gier komputerowych. W tym drugim przypadku wiadomo, że chodzi o dobrą zabawę historią czy w historię, szczególnie w odniesieniu do gier typu FPP (ang. first person perspective) dających wrażenie bycia w innym świecie. Jak trafnie zauważył jeden z badaczy: „uwarunkowania przemysłu gier komputerowych sprawiają, że ma on charakter globalny, a w każdym razie ponadnarodowy"15. Koszty produkcji gry muszą się zwrócić. W zależności od platformy sprzętowej powinna ona być sprzedana w ilości od 100 do 150 tys. egzemplarzy. To z kolei powoduje, że gry dostosowuje się do oczekiwań konsumenta, w rezultacie jedne światy historyczne i historyczne wydarzenia są w nich nadreprezentowane (Europa), inne zupełnie nieobecne (Afryka), mimo że w wielu przypadkach gracze mogą modyfikować grę, dostosowując ją do lokalnych potrzeb i oczekiwań16.

12 K. Ziółkowska-Weiss Ewolucja tradycyjnych funkcji muzeum w narracyjne muzea multimedialne na przykładzie muzeum Fabryka Emalia Oskara Schindlera „ "Przedsiębiorczość -Edukacja” 2013 nr 9, s. 167.

Tamże.

Podajemy za S. Aleksijewicz Czasy „secondhand”. Koniec czerwonego człowieka, Czarne, Wołowiec 2014, s. 16.

P. Sitarski Obroty..., s. 53.

Tamże, s. 54. 
Drugim charakterystycznym zjawiskiem jest "gadżetyzacja” historii1". Jak wiadomo, gadżety są powszechnie wykorzystywane przez firmy lub instytucje w celach promocyjnych i reklamowych, ale są także dowodem głębokich przemian kulturowych, dziejących się tu i teraz. Jak wielokrotnie podkreślano, kultura współczesna, szczególnie ta masowa, przepełniona jest gadżetami. Ich specyficznym rodzajem są także gadżety historyczne. To np. różnego typu zabawki dla dzieci, patriotyczna odzież, przede wszystkim t-shirty, imitacje umundurowania, broni i uzbrojenia, patriotyczna biżuteria ${ }^{18}$. Na wątpliwości i dylematy towarzyszące takiej formie popularyzacji wiedzy o przeszłości i jej obecności w przestrzeni publicznej zwrócił jakiś czas temu uwagę pisarz i publicysta Krzysztof Varga, dzieląc się swoimi wrażeniami z wizyty na polach bitwy pod Verdun. W swoim felietonie Varga konfrontuje wrażenia po lekturze powieści Ericha Marii Remarque'a z pobytem w słynnym ossuarium w Douaumont, nekropolii upamiętniającej poległych żołnierzy. Oto charakterystyczny fragment:

Obok kaplicy, gdzie oddać się można modlitwie i zadumie, znajdują się wąskie schodki w dół, tam, gdzie ma swoje miejsce małe kino [...] zanim jednak wejdzie się do sali kinowej, przejść trzeba przez sklep

17 Szerzej na ten temat zob. R. Stobiecki "Gadżetyzacja" historii ?, w: Florilegium Historicum Amicorum Minera. Profesorowi Krzysztofowi Maciejowi Kowalskiemu w sześćdziesiąta rocznicę urodzin przyjaciele, koledzy, uczniowie, red. T. Maćkowski, Wydawnictwo UG, Gdańsk 2016, s. 47-54. Skrócona wersja: Jak gadżety oswajają nas z przeszłościq “"Polityka” 2015 nr 22, s. 56-59.

Z okazji 70. rocznicy Powstania Warszawskiego jedna z firm produkująca zabawki dla dzieci wypuściła specjalną serię klocków - „Powstanie Warszawskie”. Znajdziemy w niej zestawy przedstawiające powstańców na barykadach, niemieckich żołnierzy w swoich pojazdach bojowych czy też płonące zgliszcza Warszawy. Jak tłumaczy producent, zabawki mają upamiętnić powstanie warszawskie i są przeznaczone dla dzieci, które skończyły już 5 lat. W zestawie są m.in. dwie figurki: pędzący na motorze esesman, umundurowany na zielono powstaniec z obwiązaną głową. Oba legopodobne ludziki szeroko się uśmiechają. Klocki inspirowane powstaniem warszawskim są częścią kolekcji "Mała armia WW2", którą reklamuje opublikowany na YouTubie filmik promocyjny www.se.pl/wydarzenia/kraj/usmiechnieci-hitlerowcy-weselipowstancy-klocki-powstanie-warszawskie_413564.html (7.08.2014). Oto kilka wybranych komentarzy internautów: "Czy figurki rozkładających się zwłok kobiet i dzieci na ulicach też planują wyprodukować? A czy rannych palonych w szpitalach żywcem miotaczami płomieni też? TO JEST CHORE!!! To jest HISTORYCZNE wydarzenie! [tak w oryginale - M.S. i R.S.] Może jeszcze niech wyprodukują zestaw «Katyń lub «Aushwitz»??? [pis. oryginalna - M.S. i R.S.]"; "No ludzie, to tylko klocki. Dzieci mają się tym dobrze bawić a nie rozpaczać po głębokiej refleksji nad tragicznym losem powstańców... To klocki dla pięciolatków!”; „Rewelka edukacyjna. Syn gra w World of Tanks a z klocków [...] już przerobił T-34 na SU-100" (tamże). 
z pamiątkami, w którym bombarduje nas nie deszcz szrapneli i pocisków z moździerzy, ale kakofonia pstrokatych kolorów, słodka woń plastiku i gumy, tłum rozbrykanych turystów kłębi się w większej niż okopowa ciasnocie, wydając hojnie euro na śliczne suweniry, [...] tutaj jest prawdziwe eldorado dla konesera pierdółek i badziewia: breloczki, zapalniczki, ołówki, podkładki pod komputerowe myszki, magnesiki w kształcie żołnierzyków w wielkim wyborze [...]. Jedna rzecz największe na mnie robi wrażenie: pośród [...] tego całego bazarowego tałatajstwa, na półce po prawej stronie rząd ślicznych białych misiów, zdaje się, że pluszowych, a każdy z nich ma na sobie koszulkę z napisem „I love Verdun”, dopowiadać nawet nie trzeba, że słowo „love” zastąpione tu jest czerwonym sercem, gdybym nie wyćwiczył wcześniej silnej woli, mocno byłbym skłonny, by sobie takiego misia sprawić, jakaż to przyjemna, wdzięczna i wzruszająca pamiątka z miejsca zagłady człowieczeństwa. [...] Nikt tutaj kupców ze świątyni nie wypędza, raczej zdaje się, iż to kupcy właśnie są najważniejsi, biznes wygra z każdym, bi znes wygrywa nawet ze śmiercią. [wyróż. - M.S.i R.S.] ${ }^{19}$

Ten długi, wielce emocjonalny cytat, ma, jak nam się wydaje, charakter uniwersalny. W dużym stopniu można go przecież odnieść do innych miejsc pamięci, które dominują w kulturowym krajobrazie współczesności. Pluszowy miś spod Verdun staje się metaforą naszego stosunku do przeszłości, zarówno w wymiarze etycznym, jak i historycznym. Gadżety pełnią w nim funkcję świeckiego decorum, za którym zdaniem Vargi kryje się „prawdziwa” twarz kapitalizmu i swoistego przemysłu pamięci ${ }^{20}$.

Gadżetyzacja historii to przykład, jak współczesna kultura radzi sobie z przeszłością. Zasadnie można w niej szukać odpowiedzi na odwieczne pytanie - po co nam historia? Nie wydaje się, aby popularność historycznych gadżetów dało się sprowadzić jedynie do ludycznej funkcji wiedzy o przeszłości. Odrębną kwestią pozostaje zresztą problem, czy w tym przypadku można jeszcze zasadnie mówić o wiedzy. Wydaje się, że proces gadżetyzacji historii wpisuje się w szersze zjawiska, związane z przeobrażeniami obecności przeszłości w naszym życiu codziennym. Państwo, instytucje samorządowe,

19 K. Varga Pluszakispod Verdun czyli, nie będzie nas, będzie biznes „ "Duży Format. Magazyn Gazety Wyborczej" 17.07.2014 $\mathrm{nr} 29$.

20 P.T. Kwiatkowski Jakg historiq interesują się Polacy? Pytanie o kształt pamięci zbiorowej i jej przemiany po 1989 roku, w: Historia Polski od-nowa... 
prywatne i państwowe firmy, instytucje pozarządowe, kościoły, lokalne środowiska miłośników przeszłości, prowadzą swoistą grę w historię, na ustalanych przez siebie zasadach. Współczesna kultura traktuje historię instrumentalnie, nie obowiązują w tym przypadku żadne reguły czy tematy tabu.

Masowość i popularność gadżetów historycznych wiąże się chyba także z psychologiczną potrzebą współczesnego człowieka. Ludziom zanurzonym w teraźniejszości historia jawi się jako przedmiot tęsknot za utraconym światem, który pragniemy zachować. Stąd światowa popularność rozlicznych miejsc pamięci w postaci muzeów oraz idąca za tym muzealizacja, swoista pomnikomania (w Polsce zwraca uwagę przede wszystkim ten jej fragment, który manifestuje się w często wątpliwej wartości pomnikach Jana Pawła II, mamy ich już ponad dwa tysiące), heritagizacja ${ }^{21}$, zmiany w nazewnictwie ulic i placów. Owa potrzeba historii odzwierciedla się także w nowych formach obchodzenia historycznych rocznic, często z udziałem grup rekonstrukcyjnych.

Fenomen gadżetyzacji historii przepełniony jest, jak nam się wydaje, wyraźnie widoczną ambiwalencją. Jak pokazują przywoływane przykłady, grozi on sprowadzeniem wiedzy o przeszłości jedynie do jej ludycznego wymiaru, bezrefleksyjnego odtwarzania wybranych epizodów z historii, banalizacji historycznego przekazu. Świat historycznych gadżetów to świat erzatzów historycznej pamięci, figurek naśladujących prawdziwe wydarzenia. Pozbawiony prawdziwych emocji, często ulukrowany, powierzchowny, uniemożliwia zrozumienie i empatię wobec przeszłości i jej bohaterów ${ }^{22}$.

Jednocześnie jednak paradoksalnie, choćby w formie „patriotycznej odzieży" gadżety podtrzymują naszą więź z przeszłością, dokumentują dumę z narodowej historii, kreują postawy innej - [jakiej? - dop. M. S. i R. S.], identyfikacji z polskością i społecznego zaangażowania ${ }^{23}$.

Wreszcie na koniec tego wątku przywołajmy zjawisko technoentuzjazmu. Jest on rezultatem zarówno cyfrowych preferencji agend finansujących

M. Stobiecka Kłopotliwa materialność dziedzictwa przyszłości, „Turystyka Kulturowa” 2019 nr 4, S. $112-123$.

Nie sposób jednak nie zwrócić uwagi na jego inny wymiar. Mateusz Staroń, z wykształcenia historyk, jeden z założycieli firmy produkującej patriotyczną odzież, zwrócił uwagę, że: „nabywcy jego ubrań zamienią się w społecznych nauczycieli historii i uczestników wielkiej rewolucji stylu polskiego patriotyzmu [...] dzięki ich zaangażowaniu, ze sztywnego, kojarzonego z peerelowskimi uroczystościami ku czci, zamieni się w radosny, atrakcyjny, inspirujący". Podajemy za E. Turlej Moda polska, Polityka” 2014 nr 31. 
kulturę, jak i sygnalizowanych przemian cywilizacyjnych. Świat cyfrowej historiografii najlepiej odzwierciedla się we współczesnych mediach. Przykładem odnoszącym się do samego rozumienia przeszłości mogą być gry komputerowe. Abstrahując na chwilę od ich niewątpliwych walorów edukacyjnych, poznawczych i rozrywkowych, zwróćmy uwagę na ten ich wymiar, który dotyczy usankcjonowanych przez dotychczasową kulturę zasad myślenia o historii. Opcje budowania w nich alternatywnych scenariuszy dziejowych sprawiają, że jakiekolwiek odniesienie do minionych wypadków staje się po prostu zbędne. Ginie kluczowa dla tradycyjnego myślenia o przeszłości zasada referencyjności. Gracz otrzymuje przywilej panowania nad przeszłością, funkcja save/load oferuje możliwość „odwracania czasu”24. Historia w tradycyjnym znaczeniu, jak wiadomo, opierała się na koncepcji wydarzenia jako czegoś, co nieuchronnie przeminęło, co już nie trwa. Świat gier komputerowych odwołuje się do kategorii „nie-wydarzenia”, gdzie „wszystko można odwołać, powtórzyć, zmienić”. Gry historyczne kwestionują także inną kluczową zasadę dotychczasowego myślenia o dziejach, odwołującą się do linearności. Jak zauważył jeden z autorów analizujących rolę historii w grach komputerowych:

Równoważność wydarzeń przeszłych i przyszłych prowadzi do terroru prewencji, rozbrajania potencjalnej mocy wydarzeń, jeszcze zanim do nich doszło. Powoduje to ujmowanie wydarzeń historycznych nie jako rewolucji, nie ciągłości, ale raczej jako pewnej cyrkulacji wymiany i unieważniania w niezależnym, nielinearnym continuum czasowym. ${ }^{25}$

W tym sensie historia w sieci „zabija” przeszłość w dotychczasowym sensie tego słowa, na jej miejsce proponując mniej lub bardziej realistyczne (to kwestia konwencji) opowieści o przeszłości. Takie ujęcie, jak łatwo zauważyć, pozbawia historię znamion naukowości, albowiem likwiduje sam przedmiot zainteresowania historyka, czyniąc go Baudrillardowskim symulakrum. Jeszcze do niedawna historyk, bez względu na reprezentowaną przez siebie historiozofię, posługiwał się w swoich badaniach, „miękką” lub „twardą" wersją rzeczywistego alibi, która nakazywała mu wierzyć, że studiuje

24 R. Bomba Historia w grach komputerowych, "Historyka” 2007/2008 t. XXXVII/XXXVIII, s. 137. Por. P. Sitarski Obroty kół historii. O historiozofii w grach komputerowych, w: Historia w kulturze..., S. 53-60. 
przeszłość, która naprawdę się zdarzyła, i że nie jest ona jedynie wytworem ludzkiej wyobraźni. Niektóre formy obecności historii w sieci podważają w mniejszym lub większym stopniu to przekonanie.

\section{Modernizacja kosztem autonomii: muzea historyczne ${ }^{26}$}

Wskazane wyżej zjawiska dotykające historiografii nie omijają muzeów. Komercjalizacja, gadżetyzacja oraz technoentuzjazm kumulują się w formie wszechobecnego w Polsce muzeum narracyjnego ${ }^{27}$. Dorota Folga-Januszewska i Paweł Kowal definiują ją jako efekt przemian zachodzących w muzealnictwie na przełomie XX i XXI wieku ${ }^{28}$. Charakteryzując ten typ wystawienniczy, piszą: „do zadań muzeum narracyjnego należą nie tylko zbieranie, konserwacja i przechowywanie oraz prezentowanie i promowanie informacji o zbiorach. Inicjatorzy, formalni organizatorzy danej instytucji kultury lub/i realizatorzy ekspozycji wykazują ambicję opowiedzenia przy pomocy ekspozycji jakiejś wyodrębnionej historii. Jej celem jest nie tylko prowadzenie narracji, ale też zaproszenie do dyskusji na temat prezentowanego wydarzenia czy zjawiska. W związku z tym rozszerza się zasób metod eksponowania przedmiotów z zastosowaniem zarówno tradycyjnych [...], jak i nowoczesnych technik prezentacji, w tym wirtualizacji przekazu. Twórcy ekspozycji narracyjnej odwołują się jednocześnie do poznawania poprzez zmysły [...], ale także przywiązują wagę do roli emocji w odbiorze"29.

Probierzem sukcesu muzeum narracyjnego w Polsce są wysokie statystyki odwiedzin w Muzeum Powstania Warszawskiego i Muzeum Historii Żydów Polskich POLIN w Warszawie, Muzeum II Wojny Światowej w Gdańsku, Muzeum Fabryki „Emalia” Oskara Schindlera czy Muzeum Podziemi

Ta partia tekstu bazuje na badaniach prezentowanych w: M. Stobiecka Natura artefaktu, kultura eksponatu. Projekt krytycznego muzeum archeologicznego, Wydawnictwo IBL PAN, Warszawa 2020 [w druku] i stanowi zredagowaną, poszerzoną i zaktualizowaną wersję kreślonych tam rozważań odnoszących się do multimedialnych muzeów archeologicznych.

Najbardziej wyczerpująco temat został omówiony w: Muzeum i zmiana. Losy muzeów narracyjnych, red. P. Kowal, K. Wolska-Pabian, Universitas, Warszawa-Kraków 2019. Antologia, red. M. Popczyk, Universitas, Kraków 2005, s. 313-334. W Polsce najszerzej omówione w: D. Folga-Januszewska Muzeum: fenomeny i problemy, Universitas, Warszawa-Kraków 2015. 
Rynku w Krakowie ${ }^{30}$. Czynnikiem istotnie wpływającym na ich rozwój jest także cyfrowa preferencja agend finansujących kulturę w naszym kraju. Nie tylko bowiem w program modernizacji instytucji kultury wpisuje się masowa digitalizacja zbiorów, udostępnianie kolekcji on-line, oferty edukacyjne na stronach internetowych muzeów, ale także - czy może przede wszystkim w kontekście omawianych polskich muzeów historycznych - intensywne wprowadzanie na wystawy wszelkiego rodzaju multimediów. Dlatego za zasadne uznajemy rozróżnienie między muzeum narracyjnym a muzeum multimedialnym. Będziemy zatem posługiwać się terminem „wystaw multimedialnych", który, przenosząc ciężar z przekazu (narracja) na jego środki (multimedia), kładzie nacisk na aspekt technologiczny dominującego modelu ekspozycyjnego. Decyzji dokonujemy w odniesieniu do pytania o to, na ile polskie muzea, korzystające ze zdobyczy technologii i zwrotu cyfrowego, w istocie realizują model opisany przez Folgę-Januszewską i Kowala? Czy rzeczywiście wystawy, najczęściej określane jako narracyjne, zapraszają zwiedzających do dyskusji na temat prezentowanych historii? Na ile zaś oferują nam gotowe historie, opowieści-produkty, gadżety nastawione na przyciąganie mas zwiedzających, skrzętnie spreparowane w procesach modernizacji wystaw? By odpowiedzieć na postawione wyżej pytania, podejmiemy próbę dokonania bilansu powszechnego funkcjonowania wystaw narracyjnych, kładąc nacisk przede wszystkim na ich multimedialny charakter.

Pierwszym, niewątpliwym atutem tych wystaw jest ich inkluzywny i partycypacyjny charakter. Multimedialne wystawy są dostępne dla każdego zwiedzającego, niezależnie od wieku, poziomu wiedzy czy stopnia sprawności. Angażując zmysły, nie ograniczają wizyty na wystawie do czysto intelektualnego doświadczenia ${ }^{31}$. Ekspozycje korzystające z interaktywnych multimediów angażują multisensorycznie, wprowadzają modele poznawcze oparte na grach i zabawach i jako takie gwarantują demokratyczny dostęp do wiedzy ${ }^{32}$.

30 M. Stefanik, M. Kamel Muzea i wystawy interaktywne w Polsce - współczesna atrakcja turystyczna, "Turystyka Kulturowa” 2013 nr 8, s. 5-24. Regularnie publikowane statystyki odwiedzin są dostępne na stronach internetowych muzeów oraz $w$ raportach rocznych.

31 Estetyczne wystawy Vergo charakteryzował jako hermetyczne i skierowane do wąskiego grona specjalistów, zaś wystawy kontekstualne operujące dużą ilością materiałów tekstowych opierały się na poznaniu intelektualnym. Zob. P. Vergo Milczący obiekt...

32 Zob. np. J. Kidd Museums in the New Mediascape. Transmedia, Participation, Ethics, Routledge, Surrey-Burlington 2014, s. 71-86. 
Ich inną bezdyskusyjną zaletą, docenioną także w muzealnictwie archeologicznym, jest możliwość obrazowania „niemożliwego", gwarancja dostępu do odległych miejsc i czasów, które trudno sobie wyobrazić, a tym bardziej zrozumieć. Nie ogranicza się do wirtualnych rekonstrukcji wymierzonych na percepcję wzrokową, a chodzi również o formy ekspozycyjne, które odtwarzają zapach, doznania dotykowe czy dźwięki. Dzięki budowaniu swoistego muzealnego krajobrazu zmysłów (sensescape) odległa przeszłość staje się bliska, odczuwalna i wciągająca. Zabytki o nieokreślonych i niezrozumiałych dla masowego odbiorcy funkcjach zostają wprzęgnięte w holistyczne rekonstrukcje, gwarantując immersyjne przeżycie. Przykładem mogą być wirtualne rekonstrukcje architektury, którą trudno sobie wyobrazić, patrząc na wybrakowane fundamenty in situ ${ }^{33}$. Poprzez zróżnicowane sposoby obrazowania i rekonstruowania obiektów zarówno materialnych, jak i niematerialnych, multimedialne wystawy zapewniają zwiedzającym nie tylko obraz przeszłości, lecz także środki do tego, by go zmysłowo "poczuć".

Kolejny walor wystaw multimedialnych wynika bezpośrednio z postulatów zwrotu cyfrowego: zintensyfikowanego zbierania, łączenia i przetwarzania danych. Wystawy operujące wirtualnymi mediami są, jak zauważa Danuta Minta-Tworzowska, „stale in-progess"34. W praktyce zapewnia to muzeum możliwość ustawicznej aktualizacji eksponatów, co ma duże znaczenie dla zmieniającego się stanu wiedzy.

Nie bez znaczenia jest też estetyczny wymiar wystaw multimedialnych. Utarło się myśleć o ekspozycjach historycznych, ale też etnograficznych czy archeologicznych jako tych, które prezentują nieszczególnie atrakcyjne manekiny w strojach z epok lub też szeregi zakurzonych gablot wypełnione obiektami o dyskusyjnej wartości estetycznej. Ekspozycje multimedialne tymczasem mają wizualnie niewiele wspólnego z tymi utartymi schematami prezentacji przeszłości. Często wymagają specjalnego oświetlenia, ciemnych sal, tworząc nastrój tajemnicy i zagadki, która intryguje i wciąga zwiedzających w prowadzoną narrację. Nie tylko organizacja przestrzeni i efekty

D. Favro To be or not to be in past spaces: Thoughts on Roman immersive reconstructions, w: Re-Presenting the Past: Archaeology through Image and Text, ed. by S. Bond, S. Houston, Oxbow Books, Oxford 2012, s. 151-168. szłości przez archeologów, w: Digitalizacja dziedzictwa archeologicznego. Wybrane zagadnienia, red. R. Zapłata, Wiedza i Edukacja, Lublin 2011, s. 326. 
świetlne, lecz także dobrze zaprojektowane tablety, eksponaty cyfrowe, wizualizacje zwracają uwagę zmianą podejścia do ekspozycyjnej estetyki i tworzą wyraźną przeciwwagę dla utrwalonych schematów znanych z tradycyjnych muzeów. Z nowym typem muzealnego doświadczenia estetycznego możemy zetknąć się w większości polskich muzeów narracyjnych - Muzeum Podziemi Rynku w Krakowie, Muzeum Fryderyka Chopina, Muzeum Powstania Warszawskiego i Muzeum Historii Żydów Polskich POLIN w Warszawie, Muzeum II Wojny Światowej w Gdańsku, w Muzeum Śląskim w Katowicach, by wymienić tylko kilka z ekspozycji zanurzonych w tajemniczym półmroku.

Mimo licznych i niezaprzeczalnych zalet wystawy multimedialne zmagają się z całym szeregiem poważnych problemów, które wpływają na percepcję zwiedzających, kształtują specyficzny rodzaj wiedzy o przeszłości, a przez to oddziałują na sposób myślenia o historii.

Pierwszy poważny mankament wynika bezpośrednio z walorów multimedialnych wystaw - możliwości dynamicznego przetwarzania danych, ciągłej mutacji i estetyzacji. Gdzie prowadzi zwiedzających ta wciągająca i czarująca narracja? Multimedialna wystawa wiedzie w hiperrealistyczną przestrzeń, w której wszystko jest możliwe, zarazem stanowiąc subiektywną wizję projektanta, kuratora lub/i badacza. Totalizująca i immersyjna rzeczywistość ma często niewiele wspólnego z tym, co z całą pewnością udaje się wyekstrahować z danych. Ten sposób prezentacji otwiera się na nadpisywanie historii, modelowanie jej podług określonych agend, nie zawsze wymierzonych w eksponowanie wielogłosowości ${ }^{35}$. Nie ma w nim zatem „zaproszenia do dyskusji na temat prezentowanego wydarzenia czy zjawiska"36 oferowanego przez muzeum narracyjne. To, z czym możemy się zetknąć, to raczej instrumentalizacja opowieści historycznej przebiegająca subliminalnie, bowiem pokryta feerią mieniących się multimediów, które angażują i utrwalają przekonanie o słuszności i adekwatności kreślonej w muzeum wizji.

Ważnych argumentów i przykładu w tej dyskusji dostarcza tekst na temat narracji w Muzeum Powstania Warszawskiego. Autorka zarzuca muzeum prezentację jednoznacznie politycznej agendy i podporządkowanie narracji jednej wizji historii, wskazując, że z narracji powstaniowej zostały wyrugowane kobiety i zwierzęta. Zob. M. Lorenc Muzeum (nie)pamięci. Koń a Muzeum Powstania Warszawskiego, w: Nowa Humanistyka. Zajmowanie pozycji, negocjowanie autonomii, red. P. Czapliński, R. Nycz, D. Antonik, J. Bednarek, A. Dauksza, J. Misun, Wydawnictwo IBL PAN, Warszawa 2017, s. 619-636. W podobnym duchu, podkreślając jednotorową interpretację historyczną, o Muzeum Fabryka „Emalia” Oskara Schindlera: A. Ziębińska-Witek Totalitaryzm wnowych muzeach historycznych, w: Historia Polski od-nowa..., s. 26-44. 
Manipulacja danymi prowadząca do prezentowania subiektywnego obrazu „pięknej” lub „jedynej słusznej” przeszłości stanowi bodaj najpoważniejszy zarzut wobec multimedialnych wystaw. Zwraca jednak także uwagę na pozorną rewolucję, która zaszła w muzeach. Muzeum narracyjne w swoich założeniach zachęcać miało do „poznawania poprzez zmysły”" Tymczasem antropolodzy zmysłów twierdzą wręcz, że „pomimo całego szeregu innowacji i alternatyw wobec modelu wystawy opartego na prezentacji obiektów w szklanych gablotach ukierunkowanego na wizualną percepcję, te nowe formy wystawiennicze i ich bezkrytyczna ufność w technologię [...] sprawiły, że muzea są bardziej niż kiedykolwiek związane z postrzeganiem wzrokowym" ${ }^{\prime 3}$. Te wnioski kierują ku rozumieniu wirtualności w muzeach nie jako alternatywy wobec tradycji wystawiennictwa, ile raczej jako jej stechnologizowanej, nadal okocentrycznej, kontynuacji. Brytyjscy badacze w 2017 roku udowodnili na kilku przykładach muzeów archeologicznych, że multimedialne wystawy nie oferują zwiedzającym nic ponad „odświeżoną wersję" tradycyjnych narracji o przeszłości ${ }^{39}$. Cyfrowe metody zostały „nałożone” na analogowe schematy, co: 1) znów sprowadza muzeum do roli okocentrycznej instytucji hołdującej wizualizacji; 2) nie wykorzystuje potencjału cyfrowych technologii w muzealnictwie; 3) nie pozwala zwiedzającemu na zbudowanie swojej własnej, subiektywnej wizji przeszłości, gdyż prezentuje wiedzę "gotową".

Wizja przeszłości, o ile generowana jest na podstawie modeli i algorytmów, dla wielu stanowi wiarygodną reprezentację, w której trudno wyłonić elementy do zakwestionowania. Przy prostym założeniu, że modele są tworzone w ramach negocjowanej i kolektywnej pracy ludzi (grafików, badaczy, projektantów, informatyków) i nie-ludzi (komputery, specjalistyczne oprogramowanie), zwiększa się wiarygodność wirtualnych narracji muzealnych. W takim sensie cyfrowy eskapizm - ucieczka w symulacje, wirtualne pomoce i inne multimedia, polegałaby na tworzeniu wirtualnych, immersyjnych środowisk, które za sprawą procesu komputerowego generowania

37 Tamże.

38 C. Classen, D. Howes, The Museum as Sensescape:Western Sensibilities and Indigenous Artifacts, w: Sensible Objects. Colonialism, Museums and Material Culture, ed. by C. Gosden, E. Edwards, R.B. Phillips, Berg, Oxford-New York 2006, s. 216.

39 T. Coppelstone, D. Dunne Digital Media, Creativity, Narrative Structure and Heritage, "Internet Archaeology" 2017 No. 44, https://doi.org/10.11141/ia.44.2 (3.01.2020). 
mają gwarantować obiektywną wizję przeszłości ${ }^{40}$. W tym sensie nie treść reprezentacji, lecz użyte narzędzia gwarantują zobiektywizowany obraz minionych dziejów.

Kolejną kwestią w dyskusji o multimedialnych wystawach jest problem bezmyślnego stosowania technologii w przestrzeni muzealnej, swoista gadżetyzacja muzeum. Wiele z muzeów decyduje się na wprowadzenie np. interaktywnych tabletów z informacjami lub grami, zapominając o tym, że sprzęty się psują, zwłaszcza kiedy są narażone na bezrefleksyjne klikanie niecierpliwych zwiedzających ${ }^{41}$. Takie sytuacje są nagminne, czego przykładem są często niedziałające eksponaty. Część multimedialnych eksponatów jest stale narażona na uszkodzenia, które wynikają z tego, że obiekty są traktowane jak zabawki. Jenny Kidd, specjalistka w zakresie użycia multimediów w muzeach, zauważa, że wirtualne eksponaty niosą za sobą widmo trywializacji przesłania wystawy. Jeśli nie są wystarczająco dobrze przygotowane, mogą nie mieć wiele wspólnego z wielozmysłowym zaangażowaniem zwiedzających, a raczej zostać potraktowane tylko i wyłącznie jako rozrywkowe gadżety ${ }^{42}$.

Oddzielnego komentarza wymaga wprowadzenie do przestrzeni ekspozycyjnej interaktywnych pomocy edukacyjnych bez odniesienia do prowadzonej narracji. Z taką sytuacją można spotkać się w Galerii Faras Muzeum Narodowego w Warszawie, gdzie jedna z najważniejszych kolekcji zagranicznych zabytków w zbiorach polskich została uzupełniona o multimedialne tablety. Informacje prezentowane na tabletach odnoszą się do cennych malowideł z katedry Faras - zwiedzający może zobaczyć wirtualną rekonstrukcję i przeczytać opisy malowideł, te jednak są eksponowane kilka sal dalej. O ile trudno mieć zastrzeżenia do sposobu eksponowania autentycznych przedstawień zaaranżowanych w sali stylizowanej na wnętrza katedralne, o tyle jednak można się zastanawiać nad zasadnością wprowadzenia tabletów, które dostarczają informacji niemożliwych do porównania z zachowanymi zabytkami, a w zastanym kontekście galeryjnym - nawet nieprzydatnych.

40 M. Stobiecka Digital Escapism. How Objects Become Deprived of Matter, "Journal of Contemporary Archaeology" 2018 No. 5 (2), s. 194-212.

41 J. Kidd Museums in the New Mediascape..., s. 87-102.

42 Tamże, s. 100. Mocno wątpliwym, nie tylko pod względem etycznym, rozwiązaniem jest także pojawienie się w amerykańskich muzeach Holokaustu hologramów świadków Zagłady. Zanim wszyscy świadkowie i ocaleńcy umrą (to oficjalne wyjaśnienie), instytuty Holokaustu tworzą ich hologramy, które są wprowadzane na wystawy i z którymi swobodnie można rozmawiać, ponieważ pytania zwiedzających są obliczane przez algorytm i generują uprzednio nagrane odpowiedzi świadków: $w$ ww.youtube.com/watch?v=w83pe-onoUUधt=4S (7.01.2020). 
Opisany przykład dokładnie ilustruje, w jaki sposób muzea wpadają w pułapkę bezmyślnej gadżetyzacji, gdzie wiara w to, że jedna zabawka unowocześni wystawę, przysłania krytyczny namysł nad tym, co w istocie zmienia jeden, kosztowny obiekt w prezentowanej narracji.

Nakreślone tu zarzuty nie dotyczą oczywiście wszystkich wystaw multimedialnych, lecz tych, których twórcy przyjęli postawę bezkrytycznego technoentuzjazmu, wyznając wiarę w to, że od świadectw bardziej interesujące są różnorakie symulakra, zaś wystawa multimedialna to „swoista biblia pauperum dla słabo wyedukowanego i stroniącego od książek społeczeństwa"43. Rezultatem tak rozumianego technoentuzjazmu i multimedialnej gadżetyzacji jest wyeliminowanie $\mathrm{z}$ wystaw materialnych świadectw przeszłości ${ }^{44}$. Zamiast na wystawy - trafiają do magazynów, gdzie poddają się upływowi czasu i oczekują na konserwację. Ta jednak nie kalkuluje się w muzeum multimedialnym, o czym bardzo rzadko się wspomina - w końcu koszty modernizacji nowoczesnych sprzętów, aktualizacja i serwisowanie tabletów, nie mówiąc już o pełnej wymianie technologicznych pomocy, znacząco obciążają budżet instytucji kultury ${ }^{45}$. To, o czym równie nieczęsto się dyskutuje przy muzealnym „boomie” multimedialnym, jest tempo starzenia się technologicznych pomocy wobec gwałtownego ich rozwoju ${ }^{46}$.

Wyjście od technologicznie wspieranej narracji kosztem obiektów powoduje, że muzeum przestaje pełnić funkcję depozytariusza zbiorów. Marginalizuje rolę oryginalnych świadectw za cenę nowoczesnego image'u. Za

43 P. Majewski Do kogo należą muzea historyczne?, referat wygłoszony na XX Powszechnym Zjeździe Historyków w Lublinie, 18-20.09.2019, http://xxpzhp.umcs.lublin.pl/Referaty/Piotr\%20Majewski,\%20DO\%20KOGO\%20NALEŻĄ\%20MUZEA.pdf (7.01.2020).

Maria Poprzęcka zwraca uwagę na odwrotny trend, pozytywnie komentując jedną z nielicznych "niemultimedialnych" wystaw otwartych w ostatnich latach w Polsce, wystawę stałą Muzeum Warszawy „Rzeczy warszawskie”, M. Poprzęcka Impas. Opór, utrata, niemoc, sztuka, Fundacja Terytoria Książki, Gdańsk 2019.

Muzealnicy podkreślają koszty utrzymania drogich sprzętów multimedialnych, potrzebę nieustannego serwisowania przy częstym braku wyszkolonej do tego kadry. Klasyczną już sytuacją opisywaną przez pracowników muzeów jest brak aktualizacji np. tabletów. Urządzenia zakupione 10 lat temu nie mogą być już aktualizowane, ponieważ dostawca oprogramowania nie przewiduje nowych wersji dla starszych modeli sprzętowych. Zasadą dla muzeum multimedialnego, jak twierdzi dyrektor "muzeum przyszłości” w Norymberdze [Deutsches Museum Nürnberg], jest wymiana wystawy stałej wraz ze sprzętami co dwa lata (w przypadku tradycyjnej wystawy to 10 lat). 
Bjørnarem Olsenem, broniąc „rzeczy” muzealnych ${ }^{47}$, zwracamy uwagę na wystawienniczą asymetrię, w ramach której zastępuje się autentyczne zabytki symulakrami ${ }^{48}$. Nie chodzi o to, by rezygnować z technologii - lecz o to, by używać jej w równowadze i z rozwagą. Wystawy budowane na podstawie bezkrytycznej aplikacji technologii w tym sensie są nie tylko otwarte na manipulacje historyczne, odrealnione, ale w dalszej perspektywie skutkują ignorancją wobec zabytków czy wręcz nawet rozczarowaniem, gdy zwiedzający będzie miał z nimi stycznośćs ${ }^{49}$. W zagruzowanych elementach architektonicznych trudno będzie dojrzeć monumentalną świątynię, a w niepozornym krajobrazie leśnym - miejsce rozgrywki ważnej bitwy. Multimedialne wystawy, ocierające się już nie o technoentuzjazm, a technofetyszyzm, w tym sensie oferują zwiedzającym odrealnioną podróż do pełnej barw, zachwycającej przeszłości odartej z auratycznych i oryginalnych świadectw materialnych, kwestionując tym samym rolę artefaktów w historii ${ }^{50}$.

\section{Uwagi końcowe}

Z wyżej wymienionych powodów nowoczesna misja muzeum nie powinna ograniczać się do ekstensywnej aplikacji multimediów. Rozważając przenikające się zjawiska gadżetyzacji, komercjalizacji i technoentuzjazmu w równej mierze dotykające samej historii, jak i muzeów historycznych stanowiących kanał ważny dla transmisji wiedzy naukowej i komunikacji ze społeczeństwem, chcemy podkreślić, że nie chodzi nam tutaj o przywrócenie

47 B. Olsen W obronie rzeczy. Archeologia i ontologia przedmiotów, przeł. B. Shallcross, Wydawnictwo IBL PAN, Warszawa 2013.

48 J. Baudrillard Symulakry i symulacja, przeł. S. Królak, Sic!, Warszawa 2005.

49 M. Pawleta, R. Zapłata Obrazowanie przeszłości w świetle nowych mediów - technologii cyfrowych, w: Digitalizacja..., s. 335-353.

Monika Stobiecka w roku akademickim 2018/2019 przeprowadziła obserwacje na grupie studentów (licząca 17 osób grupa studentów studiów licencjackich). Próba jest zbyt mała, by wyciągać daleko idące wnioski, lecz warto wspomnieć, że jedynie troje spośród 17 studentów wyrażało się pozytywnie o multimediach wprowadzanych w warszawskich muzeach. Przedmiotami ich krytyki były: przestarzały charakter multimediów, ich wyłączne nastawienie na percepcję wizualną, chaos i „przebodźcowanie”. Od wystaw oczekiwali mikrohistorii, kontaktu z zabytkiem, estetycznego przeżycia, refleksji, zwracali równocześnie uwagę na to, że multimedia odciągają uwagę od oryginalnych obiektów. Podobne wnioski nakreślił Piotr Kosiewski w odniesieniu do cyfrowych preferencji obecnego rządu, w: P. Kosiewski Muzeum i narracja. Kilka uwag, w: Muzeum i zmiana..., s. 61. 
XIX-wiecznych modeli rozumienia i uprawiania historii czy pochodzącej z tej samej epoki wizji muzeum.

Chcemy jednak zaznaczyć, że nieuchronne procesy wynikające z rozwoju technologii, przeobrażeń społeczno-gospodarczych późnego kapitalizmu czy, wreszcie, zmiany naszego stosunku do przeszłości nie powinny radykalnie wpływać na autonomię historii w ogóle, a także jej obrazu w muzeum historycznym. Przesłonięcie świadectw i historii multimedialnymi zabawkami o często dyskusyjnych walorach w istocie bowiem podważa misję muzeum i tradycyjnego, i ukierunkowanego na zmianę. Odwołujemy się w tym miejscu do dyskutowanej w Kioto w 2019 roku nowej propozycji definicji muzeum, która nie została przyjęta ze względu na sprzeciw zwolenników dotychczasowego sposobu jego definiowania ${ }^{51}$. Obowiązująca definicja kładzie nacisk na zbiory i wszelkie związane z nimi praktyki (konserwacja, opracowanie, udostępnienie itd.). Tymczasem zbiory nie są wcale istotne w multimedialnym muzeum narracyjnym, o czym dowodzi chociażby dyskusja wokół Muzeum Historii Żydów Polskich POLIN, a zwłaszcza komentarze dotyczące ekspozycji artykułowane przez Jacka Leociaka ${ }^{52}$. Zamiast oryginalnych gruzów, zwiedzający w muzeum oglądają te sztuczne, symulakra zgliszczy wykonane z papier-mâché. W nieodległej przyszłości możemy się pewnie zatem spodziewać cyfrowych gruzów, gruzów w poszerzonej rzeczywistości, gruzów wirtualnych, a także symulacji zagruzowania. Ironia nie jest tu rzeczą przypadku, ponieważ zjawiska fetyszyzacji technologii podważają zasadność zbierania, zachowywania, konserwowania, magazynowania, a także wystawiania oryginalnych eksponatów w muzeum. Muzeum w takim sensie traci rację bytu.

Kolejne postulaty wiążą się z kolei z głosowaną, nową propozycją definiowania muzeum. Wskazano w niej, że muzeum to instytucja demokratyczna, inkluzywna, polifoniczna, promująca krytyczny dialog o przeszłościach (pasts) i przyszłościach (futures) $)^{53}$. Z tego względu prezentowanie „jedynej słusznej” wizji przeszłości w multimedialnym muzeum narracyjnym nie jest wymierzone w budowanie nowoczesnej platformy wymiany myśli. Zamiast otwartej instytucji dialogu, miejsca historycznej debaty uwzględniającego wielogłosowość, to muzeum w realiach polskich oferuje wizje upolitycznione, zależne od

G. Kendall Adam, ICOM unveils new museum definition, 31.07.2019, www.museumsassociation. org/museums-journal/news/31072019-icom-reveals-updated-museum-definition (7.01.2020). krytykapolityczna.pl/kultura/leociak-gruz-z-papier-mache-rozmowa/2015/ (7.01.2020). 
poglądów agend je finansujących. Klasycznym przykładem byłby tu konflikt wokół Muzeum II Wojny Światowej w Gdańsku ${ }^{54}$. W istocie narracja dotyczyła tutaj wielu przeszłości (pasts), a została zaatakowana jako ta, która powinna prezentować jedną przeszłość (past). Proponujemy zatem muzeum historyczne wolne od presji bieżącej polityki, ukierunkowane na krytyczny dialog, włączające w debatę na temat wielu przeszłości ${ }^{55}$. Za Pawłem Kowalem można tutaj wskazać na świadomą postawę dyrektorów pielęgnujących taki etos: „dyrekcja muzeum narracyjnego, które dotyczy ważnego wydarzenia czy procesu historycznego w percepcji społecznej, ma być rodzajem władzy publicznej dbającej o to, by opowiadana w muzeum historia nie była zniekształcana, by bohaterowie, którzy znaleźli się na ekspozycji i mają niejako prowadzić dialog ze zwiedzającymi, cieszyli się ze strony dyrekcji placówki swego rodzaju opieką prawną"56.

Wreszcie zaś, ostatnim postulatem jest zachęta do budowania takiej wizji muzeum, w którym krytycznemu namysłowi nad przeszłościami towarzyszyłaby efektowna, trafiająca do młodych ludzi prezentacja. Badacze zwracają uwagę na to, że w polskich muzeach brak szeroko zakrojonych badań na temat preferencji i potrzeb zwiedzających. Napawa jednak nadzieją na zmiany wyróżnienie grup zwiedzających w zależności do ich relacji wobec technologii (pokolenia X,Y,Z). Obecnie mamy do czynienia z sytuacją, w której za wprowadzanie do muzeum technologii odpowiadają pokolenia nie wyrosłe z internetem czy smartfonami, a odwołujące się m.in. do generacji młodych odbiorców urodzonych i żyjących w ramach sieci. Błędnym założeniem jest, jak sądzimy, wiara w to, że osoba, dla której tablet czy smartfon to codzienność, chce muzeum, tę „inną przestrzeń”, poznawać za pomocą tych samych mediów. Jeśli muzeum ma oferować nowe doświadczenia, to w tym przypadku zapewne bardziej edukacyjny i paradoksalnie atrakcyjny wymiar będzie miał kontakt $\mathrm{z}$ materialnym zabytkiem niż z kolejnym zacinającym się tabletem.

Szerzej na ten temat zob. P. Machcewicz Muzeum, Znak, Kraków 2017.

Na myśl przychodzi w tym miejscu cytat z wykładu O potędze historii inaugurującego ostatni zjazd historyków w Lublinie. J. Pomorski zauważył: „Potęga historii dorównuje energii, jaka powstaje przy rozszczepieniu atomu. Może mieć niszczące lub pokojowe zastosowanie. Niewłaściwie użyta, może mieć siłę rażenia bomby wodorowej. Dostrzegliśmy to w wieku XX, gdy umysły historycznie zniewolone na dziesięciolecia zawładnęły Europą. Ale ta sama historia, inaczej opowiedziana, może być siłą napędową pozytywnej zmiany społecznej". 


\section{Abstract}

\section{Monika Stobiecka}

UNIVERSITY OF WARSAW

\section{Rafał Stobiecki}

UNIVERSITYOF ŁÓDŹ

In Defence of the Autonomy of History in the Museum

Stobiecka and Stobiecki discuss phenomena taking place within and around the field of historiography, including commercialisation, "gadgetisation" and techno-enthusiasm. In the first case, history becomes a commodity that must compete with other goods on the market. In the second case, history is treated as a game, which leads to the objectification and trivialisation of historical experience. Techno-enthusiasm, finally, is rooted in the digital preferences of the agencies sponsoring cultural institutions and their belief that an immersive vision of the past will attract more visitors to emerging cultural establishments. In contemporary Poland these phenomena intersect especially in the dominant model of the narrative museum critiqued by the authors.

\section{Keywords}

historical museum, narrative museum, techno-enthusiasm, commercialisation, gadgetisation, multimedia exhibition 